\begin{tabular}{|c|c|c|}
\hline $\begin{array}{l}\text { Editorial \& Publishing Offices : } \\
\text { MACMILLAN \& Co., LTD. } \\
\text { ST. MARTIN's STREET } \\
\text { LONDON, W.C.2 }\end{array}$ & $x^{2}$ & $\begin{array}{l}\text { Telegraphic Address : } \\
\text { Phusis, LESQUARE, LoNDON } \\
\text { Telephone Number : } \\
\text { WHITEHALL } 88_{31}\end{array}$ \\
\hline No. 3547 & SATURDAY, OCTOBER 23,1937 & Vol. I40 \\
\hline
\end{tabular}

\title{
Lord Nuffield's New Gifts to Oxford
}

A $\mathrm{N}$ Oxford that had made up its mind not to $A$ be surprised by Lord Nuffield's almost daily giving to hospitals and other institutions was agreeably staggered last week to learn that the University had been offered by him approximately $£ 1,300,000$ for three important purposes. The first of these is the erection and endowment of wards in connexion with the Radcliffe Infirmary and the other hospitals associated with the School of Medicine, particularly the wards for the special use of the new Nuffield professors. The sum promised for this is $£ 200,000$, so that Lord Nuffield's endowment of the medical school within the past twelve months amounts to the munificent sum of $22,200,000$. The second is the erection of the new laboratory of physical chemistry on a site between the Organic Chemistry Laboratory and the Department of Pathology in South Parks Road. For this a sum up to $£ 100,000$ is promised. The third and, to the general public, the most interesting, is the founding and endowment of a new college for post-graduate work in social studies, to be erected near Worcester College on the canal wharf that lies below St. Peter's Hall. For this, Lord Nuffield has given the valuable site itself, and a sum of about $£ 900,000$, about $£ 250,000$ of which will be required for the buildings.

The Oxford appeal launched last February aimed at $£ 500,000$ for definite and immediate needs, and a further $\$ 500,000$ for the endowment of new developments in any subject that looks promising. It has now reached the sum of $£ 423,000$. As the physical chemistry laboratory is one of the immediate needs, this sum now becomes $£ 523,000$, and so as regards these needs the appeal has been successful. The first major step in the ordered development of the science area in the
Parks has accordingly been taken-to proceed with the erection of the new physics laboratory for Prof. F. A. Lindemann at a cost of about $£ 80,000$; and soon will follow the second, for which already provisional plans have been prepared--the erection and equipment of the University's first laboratory for physical chemistry with the sum given by Lord Nuffield, and the sums earmarked for it in the appeal fund.

The great majority of senior members of the University welcome these gifts as, of course, they deserve to be welcomed. A few complain that they will alter the character of the University considerably and, probably, for the worse; a few wish the offer had been entirely unconditional or, alternatively, that their own department or subject had been in the position of medicine, physical chemistry or social studies. As regards the last, it is realized that the success or failure of the new college will depend much on the start it gets and, in particular, on the first warden and fellows. A long and carefully drafted letter from Lord Nuffield to the Vice-Chancellor gives some ideas of the intended college and its fellows, and others have been got from some of the principal Oxford men who are concerned. The new college is to be mainly a post-graduate one, like All Souls', with accommodation for, say, fifty residents, and principally for research and investigation. It need not be entirely devoted to social studies; other subjects may be considered. It is not intended that it be a teaching institution in the ordinary sense or that it should train undergraduates for business careers, still less that it should be a place where the newly graduated may start to research according to their fancy. It is hoped that the fellows will be mature workers, 
brought back after they have been out in the world for some years, to do large-scale team work on those social subjects on which research is urgently needed. The new college, it is hoped, will not merely be a centre for these activities in economics, politics, anthrapology, sociology and the like, but also a place where men of business and affairs, by residing there, will have an opportunity of contributing their experience to the common fund. This co-operation of academic and non-academic persons in attacking problems in the social sciences is regarded as valuable by those who, with Lord Nuffield and the Vice-Chancellor, have been thinking of the welfare of the new college. It remains to be seen how Oxford makes use of these gifts, which bring, of course, their difficulties and responsibilities with them. That it will rise to the occasion no one who knows the temper of young Oxford at the present time will question.

\section{African Agricultural Problems}

(I) Moisture and Farming in South Africa By W. R. Thompson. (South African Agricultural Series, Vol. 14.) Pp. 260. (Johannesburg: Central News Agency, Ltd ; London: Gordon and Gotch, Ltd., 1936.) 21s.

\section{(2) The Earth Goddess:}

a Study of Native Farming on the West African Coast. By G. Howard Jones. (Royal Empire Society Imperial Studies, No. 12.) (Published for the Royal Empire Society.) Pp. xii $+206+8$ plates. (London, New York and Toronto : Longmans, Green and Co., Ltd., 1936.) 12s. 6d. net. THE great diversity of African agricultural volumes. In South Africa moisture dominates the situation, and, on the west coast, anthropology.

(1) Mr. Thompson has assiduously collected a mass of information on the alleged drying up of South Africa and has critically examined the numerous explanations that have been advanced. They include the drying up of the inland Kalahari lakes, by head-stream erosion of rivers discharging into the ocean; the substitution of indigenous vegetation by exotic types such as wattle and eucalyptus with higher transpiration coefficients ; the destruction of natural vegetal cover by veld burning, and the increase in cultivated crops, both of which are alleged to lead to increased evaporation from the soil and to erosion; and finally, the gradual rising of the earth's crust in South Africa, which in effect lowers the water-table and accelerates the run-off as the rivers cut deeper and deeper.

With the obvious exception of the last, all these theories predict a suitable remedy. The most widely known is Schwarz's scheme for greatly increasing the area of the inland lakes by dams across rivers that now drain the area. Although
Mr. Thompson patiently and fairly discusses this and rival proposals, he points out that discussion is somewhat academic unless the country is really drying up. He has examined this crucial question in great detail and can find no convincing evidence for the allegation. It is, in fact, the old story: the abnormal is noted and the account preserved just because it is unusual ; and, in course of time, a series of such records presents a superficial appearance of normality to the uncritical mind. It seems clear that the popular idea that South Africa is drying up is not based on any evidence of change during historic times, but is an erroneous deduction from the peculiar meteorological conditions of the country. These may be summarized as follows : only $\mathbf{3 5}$ per cent of the surface receives more than 24 inches of rain annually; the total rainfall is variable, its distribution is unreliable, and it is markedly seasonal; the intensity is high and evaporation losses are heavy especially in summer-rainfall areas ; the run-off is also high.

Evidently, rainfall imposes limitations on South African agriculture; droughts are common and losses severe. The cultivated land is also liable to extensive erosion, and Mr. Thompson discusses its increased incidence following more intensive farming practices, and urges the paramount importance of control measures, lest South Africa should follow the same unhappy path as other countries. No visitor to the country can fail to understand the concern that is felt about erosion dangers, for, whether he travels north from the Cape to Rhodesia, or east to Natal, the signs of drastic erosion are written large in those unique and beautiful panoramas that make a visit so memorable. The main strokes of this giant chisel cannot be stayed or altered; but the surfaces it leaves can be smoothed by the prevention of sheet erosion and gulleying on cultivated and 